\title{
Stability and stabilisation of biochar and green manure in soil with different organic carbon contents
}

\author{
Joseph M. Kimetu ${ }^{\mathrm{A}, \mathrm{B}}$ and Johannes Lehmann ${ }^{\mathrm{A}, \mathrm{C}}$ \\ ${ }^{A}$ Department of Crop and Soil Sciences, Cornell University, Ithaca, NY 14853, USA. \\ ${ }^{B}$ Present address: Institute for Sustainable Energy, Environment and Economy (ISEEE), \\ Earth Sciences Building, University of Calgary, Calgary, AB, Canada. \\ ${ }^{\mathrm{C}}$ Corresponding author. Email: CL273@cornell.edu
}

\begin{abstract}
Due to its recalcitrance against microbial degradation, biochar is very stable in soil compared to other organic matter additions, making its application to soils a suitable approach for the build-up of soil organic carbon (SOC). The net effects of such biochar addition also depend on its interactions with existing organic matter in soils. A study was established to investigate how the status of pre-existing soil organic matter influences biochar stabilisation in soil in comparison to labile organic additions. Carbon loss was greater in the C-rich sites (C content $58.0 \mathrm{~g} \mathrm{C} / \mathrm{kg}$ ) than C-poor soils (C content 21.0-24.0 g C/kg), regardless of the quality of the applied organic resource. Biochar-applied, C-rich soil showed greater C losses, by $>0.5 \mathrm{~kg} / \mathrm{m}^{2}$.year, than biochar-applied C-poor soil, whereas the difference was only $0.1 \mathrm{~kg} / \mathrm{m}^{2}$.year with Tithonia diversifolia green manure. Biochar application reduced the rate of $\mathrm{CO}_{2}-\mathrm{C}$ loss by $27 \%$, and T. diversifolia increased $\mathrm{CO}_{2}-\mathrm{C}$ losses by $22 \%$ in the C-poor soils. With biochar application, a greater proportion of $\mathrm{C}$ ( 6.8 times) was found in the intraaggregate fraction per unit $\mathrm{C}$ respired than with green manure, indicating a more efficient stabilisation in addition to the chemical recalcitrance of biochar. In SOC-poor soils, biochar application enriched aromatic-C, carboxyl-C, and traces of ketones and esters mainly in unprotected organic matter and within aggregates, as determined by Fourier-transform infrared spectroscopy. In contrast, additions of $T$. diversifolia biomass enriched conjugated carbonyl-C such as ketones and quinones, as well as $\mathrm{CH}$ deformations of aliphatic-C mainly in the intra-aggregate fraction. The data indicate that not only the stability but also the stabilisation of biochar exceeds that of a labile organic matter addition such as green manure.
\end{abstract}

Additional keywords: biochar, SOC stabilisation, SOM degradation, stability.

\section{Introduction}

Biochar is highly recalcitrant to decomposition (Schmidt and Noack 2000), typically has a high ratio of carbon (C) to nitrogen $(\mathrm{N})$, and has the ability to increase soil cation exchange capacity (CEC) (Tryon 1948; Mikan and Abrams 1995; Topoliantz et al. 2002; Lehmann et al. 2006; Liang et al. 2006). Due to its long half-life (Baldock and Smernik 2002), biochar could be one of the best approaches to sequester $\mathrm{C}$ in soils, contributing to a net carbon dioxide withdrawal from the atmosphere (Lehmann 2007; Laird et al. 2009). In addition to improving nutrient retention ability (Glaser et al. 2002; Bélanger et al. 2004; Major et al. 2009), water-holding capacity (Glaser et al. 2002), and microbial functions of soils (Thies and Rillig 2009), substantial increases in soil organic carbon (SOC) have been shown with the application of biochar in highly SOC-depleted soils (Kimetu et al. 2008; Novak et al. 2010). Biochar can thus be a valuable tool in enhancing fertility and $\mathrm{C}$ stocks in soils that are highly depleted of SOC.

However, the ability of any soil to stabilise both native and added $\mathrm{C}$ varies to a great extent depending on the chemical and physical properties of the mineral matrix as well as the morphology and the chemical structure of the pre-existing soil organic matter (SOM) (Baldock and Skjemstad 2000). In the recently developed C saturation concept, Six et al. (2002),
Stewart et al. (2007, 2008), and Gulde et al. (2008) indicate that the physicochemical characteristics of soils put a ceiling on the protective capacity of SOC pools by soil aggregates and clay minerals, which limits increases in SOC even with the addition of organic inputs (e.g. Campbell et al. 1991; Paustian et al. 1997; Solberg et al. 1997; Kimetu et al. 2008). Six et al. (2002) and Stewart et al. (2007) suggested that soils with high OC status have a lower $\mathrm{C}$ stabilisation efficiency than soils of low $\mathrm{OC}$ status. We therefore hypothesise that stabilisation of biochar $\mathrm{C}$ will be higher in soils containing low amounts of OC than in those containing high amounts of OC. While we understand that there are complex interactions between the quality of added $\mathrm{C}$ and both the quality and quantity of pre-existing SOM, we cannot yet predict the dynamics of stabilisation for biochar added to a given soil.

These relationships may be further complicated by the effect that biochar may have on existing SOM. Wardle et al. (2008) showed greater losses of an organic horizon after the addition of char; however, other authors did, in some cases, observe a lower C emission after biochar addition to soil (Kuzyakov et al. 2009; Spokas et al. 2009; Liang et al. 2010). Therefore, the main objective of this study was to investigate how status of preexisting SOM influences biochar stabilisation in soil in comparison to labile organic additions from green manure. 


\section{Materials and methods}

\section{Study site}

The experimental sites are in South Nandi district of western Kenya $\left(34^{\circ} 94^{\prime} 23^{\prime \prime} \mathrm{E}\right.$; $\left.00^{\circ} 13^{\prime} 44^{\prime \prime} \mathrm{N}\right)$ with an altitude of $1542-1828 \mathrm{~m}$ above sea level. The sites receive $\sim 2000 \mathrm{~mm}$ mean annual rainfall in a bimodal distribution, with 2 growing seasons per year, March-July and September-January. Mean annual temperature is $19^{\circ} \mathrm{C}$. Soils are extremely deep, dark reddish brown soils with friable clay and thick humic top soils principally developed on biotite-gneisses parent material which are classified as Humic Nitosols (FAO-UNESCO 1997). The natural vegetation of these sites is composed of tropical rainforest of Guineo-Congolian species.

A series of field experiments was established along a degradation gradient on the same soil type and under identical climatic conditions but containing different amounts and quality of SOC. The degradation gradient is a function of different periods $(5,20,35$, and 105 years $)$ of permanent cereal cropping and is captured in decreasing SOC contents (Table 1), nutrients, and productivity (Kinyangi 2008; Ngoze 2008; Ngoze et al. 2008). Throughout the manuscript, we call fields that have been cultivated for 5 years (with an average of $58.0 \mathrm{~g} \mathrm{C} / \mathrm{kg}$ soil of pre-existing SOC) 'C-rich', for 20 years (with an average of $32.0 \mathrm{~g} \mathrm{C} / \mathrm{kg}$ soil of pre-existing SOC) 'moderately C-rich', and for 35-105 years $(21.0-24.0 \mathrm{~g} \mathrm{C} / \mathrm{kg}$ soil of pre-existing $\mathrm{SOC})$ 'C-poor' (Table 1). Such chronosequences substitute time for space and have to be carefully selected to assure similar properties along the time series (Huggett 1998). Climate varied only slightly between the sites (Kimetu et al. 2008). Farms of different time since conversion were in close proximity, from $\sim 100 \mathrm{~m}$ to a few kilometres, with often similar distances between farms of the same time since conversion (see accessory publication on journal's website). All farms were in plateau position with minimal slope. The pre-existing SOC content in

Table 1. Soil characteristics for the chronosequence sites $n=3$ for $\mathrm{C}$ and $\mathrm{N}$; n.d., no data; values in parentheses are standard errors

\begin{tabular}{lcccccc}
\hline $\begin{array}{l}\text { Time of } \\
\text { cultivation } \\
\text { (years) }\end{array}$ & Clay & $\begin{array}{c}\text { Silt } \\
(\%)\end{array}$ & Sand & \multicolumn{2}{c}{$\begin{array}{c}\mathrm{N} \\
(\mathrm{mg} / \mathrm{g})\end{array}$} & $\begin{array}{c}\text { Microbial } \\
\text { biomass C } \\
(\mathrm{mg} \mathrm{C} / \mathrm{kg} \text { soil) }\end{array}$ \\
\hline 0 & 49 & 25 & 26 & $85(1.7)$ & $7.0(0.5)$ & $4.8(0.7)$ \\
5 & 50 & 25 & 25 & $58(1.9)$ & $5.4(0.5)$ & $2.6(0.7)$ \\
20 & 40 & 15 & 45 & $32(2.3)$ & $3.3(0.2)$ & n.d. \\
35 & 45 & 15 & 40 & $24(2.0)$ & $2.2(0.1)$ & $2.9(0.2)$ \\
105 & 42 & 13 & 45 & $21(0.7)$ & $1.8(0.1)$ & $0.9(0.3)$ \\
\hline
\end{tabular}

this soil sequence ranges from 85 to $21 \mathrm{mg} \mathrm{C} / \mathrm{g}$, with total $\mathrm{N}$ between 7.0 and $1.8 \mathrm{mg} \mathrm{N} / \mathrm{g}$ and microbial biomass decreasing from 4.8 to $0.9 \mathrm{mgC} / \mathrm{kg}$ with increasing age of conversion (Table 1). A more detailed description of these sites can be found in Kimetu et al. (2008), Kinyangi (2008), and Ngoze et al. (2008).

\section{Experimentals}

Two OC sources, Tithonia diversifolia green manure and biochar, were incorporated at the rate of $6 \mathrm{t} \mathrm{C} / \mathrm{ha}$, for 3 seasons over a 2-year period in plots across the chronosequence. These applications were done in March 2005, August 2005, and March 2006 for the first, second, and third seasons, respectively. Plots were established with a size of 4.0 by $4.5 \mathrm{~m}$, and randomly distributed in a given farm, with 3 replicate farms per conversion age and 1 replicate per farm (Kimetu et al. 2008; Ngoze et al. 2008). In addition to $C$ added to the soil as organic inputs, all plots received full fertilisation with $\mathrm{N}, \mathrm{P}$, and $\mathrm{K}(120,100$, $100 \mathrm{~kg} / \mathrm{ha}$, respectively). Maize was planted in all plots for the 3 seasons and yield data are reported in Kimetu et al. (2008). On the $T$. diversifolia plots, freshly picked $T$. diversifolia leaves were evenly spread before incorporation using a hand hoe. Biochar was produced from Eucalyptus saligna Sm. trees using a traditional kiln method whereby wood pieces are piled together, covered with leaves and twigs, and then covered with soil allowing thermal decomposition under oxygen-deprived conditions at $400-500^{\circ} \mathrm{C}$ (Brown 2009). The resulting biochar was collected in sacks and pounded into small pieces $(1-20 \mathrm{~mm})$, which were weighed, evenly spread on the plots, and then incorporated to $\sim 0.1 \mathrm{~m}$ depth using a hand hoe.

\section{Carbon dioxide measurements}

To evaluate the influence of soil degradation on $\mathrm{C}$ mineralisation, field experiments were conducted to quantify carbon dioxide $\left(\mathrm{CO}_{2}\right)$ evolution from control maize plots and maize treated with $T$. diversifolia biomass and maize treated with biochar. T. diversifolia is widely advocated as an organic soil amendment by researchers (Gachengo et al. 1999; Jama et al. 2000; Palm et al. 2001; Kimetu et al. 2004) and has a high mineralisation rate. This offered an opportunity for quantifying $\mathrm{C}$ mineralisation via $\mathrm{CO}_{2}$ evolution $v$. stable biochar with a high $\mathrm{C}: \mathrm{N}$ ratio (Table 2). The $\mathrm{CO}_{2}$ evolution measurement was done in 5- and 105-year-old conversions (representing high and low C-containing cultivated sites, respectively) as well as in a primary forest site (native vegetation) as a reference for $\mathrm{C}$ mineralisation under climax vegetation. Surface $\mathrm{CO}_{2}$ flux

Table 2. Treatment descriptions

Rate of application for the organic inputs was $6 \mathrm{tC} / \mathrm{ha}$, applied at the beginning of each season for 3 consecutive seasons. This rate remained the same for the different sites where the experiments were established. All plots including the control that did not receive any organic amendments were fully fertilised with $\mathrm{N}, \mathrm{P}, \mathrm{K}$ at the rate of 120,100 , and $100 \mathrm{~kg} / \mathrm{ha}$, respectively

\begin{tabular}{|c|c|c|c|c|c|c|c|c|}
\hline \multirow[t]{2}{*}{ Treatment } & $\mathrm{C}$ & $\mathrm{N}$ & \multirow{2}{*}{$\begin{array}{l}\mathrm{C}: \mathrm{N} \\
\text { ratio }\end{array}$} & \multirow{2}{*}{$\begin{array}{c}\text { Natural abundance } \\
\delta^{13} \mathrm{C}(\%)\end{array}$} & \multicolumn{4}{|c|}{ Macro-nutrients (g/kg) } \\
\hline & \multicolumn{2}{|c|}{$(\mathrm{g} / \mathrm{kg})$} & & & $\mathrm{P}$ & K & $\mathrm{Ca}$ & $\mathrm{Mg}$ \\
\hline Biochar & 851 & 2.2 & 387 & -25.9 & 0.3 & 2.7 & 9.8 & 1.6 \\
\hline T. diversifolia & 445 & 48 & 9 & -29.1 & 3.1 & 35.4 & 23.4 & 3.1 \\
\hline Control & - & - & - & - & - & - & - & - \\
\hline
\end{tabular}


without the litter layer was measured gravimetrically through 3 growing seasons using the soda lime technique (Edwards 1982; Grogan 1998), once per month after a bi-weekly measurement during the first 2 months to capture the initial mineralisation after site preparation (total of 30 flux measurements per treatment per farm). Measurements were done in static vented chambers (PVC pipes with an internal area of $0.0314 \mathrm{~m}^{2}$ ) placed on top of the soil with permanent rims inserted to a depth of $1 \mathrm{~m}$, using an aliquot of $10 \mathrm{~g}$ soda lime as the $\mathrm{CO}_{2}$ trap (modified from Puget and Drinkwater 2001). Two flux measurements were taken per plot with 3 plots ( 1 plot each installed on 3 different farms) for each treatment (control, $T$. diversifolia, and biochar on each 5- and 105-year-old conversion, in comparison to forest plots). Flux measurements were also done in 6-7 randomly selected spots on the untreated farm plots, which revealed minimal spatial variability within a given farm.

Soda lime traps were weighed using a Mettler Toledo weighing scale with an accuracy of up to $1 \mathrm{mg}$. Weighing was done the day before deployment after traps were predried at $100^{\circ} \mathrm{C}$ for $24 \mathrm{~h}$. They were immediately sealed in airtight, wide-mouth vials and transported for deployment in the field within $1 \mathrm{~h}$ after the pre-drying process. After exposure for $24 \mathrm{~h}$ inside the closed chamber in the field, the trap was retrieved and sealed immediately, then transported instantaneously to the laboratory for post-drying (at $100^{\circ} \mathrm{C}$ for $24 \mathrm{~h}$ ) and final weighing. The amount of $\mathrm{CO}_{2}$ absorbed by the soda lime trap was determined by mass difference between initial weight of the trap and the final weight. Appropriate blank treatments without soil were used to correct for $\mathrm{CO}_{2}$ absorption during handling (Major et al. 2010). To establish the effect of different treatments on $\mathrm{C}$ mineralisation obtained by the soda-lime technique, net $\mathrm{CO}_{2}-\mathrm{C}$ loss was calculated by subtracting $\mathrm{CO}_{2}-\mathrm{C}$ loss in control plots from $\mathrm{CO}_{2}-\mathrm{C}$ loss in plots that received either biochar or $T$. diversifolia.

\section{Soil sampling and analyses}

To investigate the influence of the added OM on entire SOC, soil was sampled using a soil auger (diameter $55 \mathrm{~mm}$ ) in all plots from the plough layer (determined to be $0-0.1 \mathrm{~m}$ ) after 3 cropping seasons $(24,13$, and 7 months after the first, second, and third seasons' application, respectively). Pooled samples from 6-7 randomly selected sampling points in each plot were thoroughly mixed in a bucket, from which a subsample was drawn, dried, and ground to pass through a 2-mm sieve. A smaller subsample of $\sim 10 \mathrm{~g}$ was ground further into fine powder for total $\mathrm{C}$ and $\delta^{13} \mathrm{C}$ analyses. A repeated measurement was done on the same sample, yielding similar results $(<10 \%$ coefficient of variation), and hence a mean of the duplicate measurements is reported. This procedure led to 3 replicate measurements (equalling to 3 farms) for each conversion age. Microbial biomass was measured on the same samples taken in September 2006, using fumigation extraction (Brookes et al. 1985).

\section{Soil fractionation}

To study C stabilisation, pooled soil samples from across 3 replicate farms from each of the selected representative conversion ages (5, 20, and 105 years) were used. A subsample of $15 \mathrm{~g}$ was taken from a main sample from each of the 3 replicate farms, pooled together, mixed thoroughly, and then fractionated by density separation using sodium iodide $\left(1.8 \mathrm{~g} / \mathrm{cm}^{3}\right)$ into free light fraction, intra-aggregate light fraction, and organo-mineral complexes following the method of Sohi et al. (2001). The various soil fractions were analysed for total C and $\delta^{13} \mathrm{C}$. Samples were analysed for organic $\mathrm{C}$ contents with a Europa ANCA-GSL CN analyser (PDZ Europa Ltd, Sandbach, UK). Natural abundance of ${ }^{13} \mathrm{C}$ for the same sample was determined on a coupled Europa 20-20 continuous flow isotope ratio mass spectrometer (PDZ Europa Ltd, Sandbach, UK) following combustion at $1000^{\circ} \mathrm{C}$. The $\delta^{13} \mathrm{C}$ values were expressed relative to Vienna-Pee Dee Belemnite (V-PDB) standard.

\section{Fourier-transform infrared analyses}

In addition, spectroscopic analyses were done on the fractions to test whether the quality of OM additions affects the quality of stabilised SOM. These investigations were done by Fouriertransform infrared (FTIR) analyses. Ground OM (0.3-0.5 mg) was embedded in potassium bromide $(\mathrm{KBr})$ pellets (99.5-99.7 mg) and measured on a Mattson mode 5020 FTIR spectrometer with a $4 \mathrm{~cm}^{-1}$ resolution and 100 scans between wavenumbers of 4000 and $400 \mathrm{~cm}^{-1}$ (Chun et al. 2004). To analyse $\mathrm{C}$ forms from the FTIR spectra, we subtracted the background of the $\mathrm{KBr}$ window, automatically corrected the baseline and smoothed the spectra, identified the peaks, and normalised the spectra on a reduced portion of the wavenumbers (4000-800 $\mathrm{cm}^{-1}$ ) using OMNIC version 7.2 (Thermo Electron Corp., Woburn, MA).

\section{Calculations of the carbon source}

The isotopic differences between the added OM that is exclusively derived from $\mathrm{C}_{3}$ plants, and the $\mathrm{SOC}$ in old conversions which were continuously cropped with maize for $>100$ years $\left(\mathrm{C}_{4}\right.$ plants), served as a tool to partition between added and native C (Bernoux et al. 1998; Spaccini et al. 2002). The carbon isotopic composition of SOC is comparable to that of the source plant material, even though small changes may occur due to isotope discrimination (Bernoux et al. 1998). Consequently, the natural abundance of ${ }^{13} \mathrm{C}$, measured by mass spectrometry, can be used to partition $\mathrm{C}$ into SOC from the different organic amendments using the mass balance equation shown below (Balesdent and Mariotti 1996; Huggins et al. 1998, 2007; Solomon et al. 2002). This approach could only reliably be interpreted in older conversions, since SOC in younger conversions was dominated by $\mathrm{C}_{3}$-derived forest $\mathrm{SOC}$, and the $\mathrm{C}$ isotopic composition does not differ between the forest SOC and the applied OC:

$$
\begin{aligned}
& \% \mathrm{C} \text { derived from added } \mathrm{OC}= \\
& {\left[\left(\delta^{13} \mathrm{C} \text { Soil }_{\text {final }}-\delta^{13} \mathrm{C} \text { Soil }_{\text {initial }}\right) /\right.} \\
& \left.\left(\delta^{13} \mathrm{C} \text { Added } \mathrm{OC}-\delta^{13} \mathrm{C} \text { Soil }_{\text {initial }}\right)\right] * 100
\end{aligned}
$$

Forest sites were included as a reference for $\mathrm{C}$ sequestration potential. 


\section{Statistical analyses}

The statistical differences between experimental treatments and ecosystem degradation stages were determined through Analysis of Variance (General ANOVA procedure) in GENSTAT version 8.2 (Rothamsted Experimental Station 2005). Mean separation was computed using least significant difference at $P=0.05$. For $\mathrm{CO}_{2}-\mathrm{C}$ loss and $\mathrm{C}$ in fractions, differences between treatments were determined by regression analysis whereby the difference between slopes of any pair of curve fits was hypothesised to be unequal to zero.

\section{Results}

\section{Soil organic carbon}

Delta ${ }^{13} \mathrm{C}\left(\delta^{13} \mathrm{C}\right)$ shifted by -1.1 to $-2.3 \%$ o towards the $\mathrm{C}_{3}$ signature with the application of either biochar or $T$. diversifolia biomass in the C-poor soils, with a slight shift $(-0.4$ to $-0.8 \%$ ) in the moderately $\mathrm{C}$-rich soils indicating $\mathrm{C}_{3}$ enrichment but no significant impact on $\delta^{13} \mathrm{C}$ signature in the $\mathrm{C}$-rich soils (Table 3 ). Consequently, in the C-poor soils, an estimated $84 \%$ of the $\mathrm{C}$ applied with biochar was found in the top $0.1 \mathrm{~m}$ of the soil at the end of the 3 seasons, while in the $T$. diversifolia plots only $24 \%$ of the $\mathrm{C}$ applied with $T$. diversifolia was found in the soil (Table 3). The recoveries in the C-rich and moderately $\mathrm{C}$-rich soils are not considered further as the differences in isotope values were insufficient.

\section{Carbon dioxide evolution}

Soil $\mathrm{C}$ loss as gaseous $\mathrm{CO}_{2}$ at the $\mathrm{C}$-poor sites significantly $(P=0.0001)$ differed as a result of applying different organic amendments, with no significant $(P=0.903)$ seasonal differences. Determined using the soda lime technique, cumulative $\mathrm{CO}_{2}-\mathrm{C}$ loss in the C-poor sites was $\sim 4.1( \pm 0.6$ s.e. $)$ $\mathrm{g} / \mathrm{m}^{2}$.day $\left(\sim 1500 \mathrm{~g} / \mathrm{m}^{2}\right.$.year) averaged over 444 days with the application of $T$. diversifolia leaf biomass, while $\mathrm{C}$ loss in biochar-applied plots was only $2.4( \pm 0.2) \mathrm{g} / \mathrm{m}^{2}$.day $\left(\sim 880 \mathrm{~g} / \mathrm{m}^{2}\right.$. year) averaged over the same time period (Fig. $1 a$ ).

Carbon loss from control plots was $\sim 3.4( \pm 0.2) \mathrm{g} / \mathrm{m}^{2}$.day $\left(1200 \mathrm{~g} / \mathrm{m}^{2}\right.$.year), which was $>300 \mathrm{~g} / \mathrm{m}^{2}$.year more than that from plots that received biochar and $\sim 270 \mathrm{~g} / \mathrm{m}^{2}$.year less than $T$. diversifolia plots (Table 3). Application of biochar thus reduced the rate of $\mathrm{CO}_{2}-\mathrm{C}$ loss by $\sim 27 \%$, while T. diversifolia increased $\mathrm{C}$ loss by $22 \%$ compared with the unamended control at the $\mathrm{C}$-poor sites. Cumulative $\mathrm{C}$ loss from the forest floor in the C-poor soils was $2.8( \pm 0.4) \mathrm{g} / \mathrm{m}^{2}$.day $\left(1000 \mathrm{~g} / \mathrm{m}^{2}\right.$.year) $(17 \%$ higher than the $\mathrm{C}$ loss in biocharapplied plots but $32 \%$ and $18 \%$ lower than $T$. diversifoliaapplied and control plots, respectively).

Although the application of $T$. diversifolia leaf biomass resulted in the highest increase in $\mathrm{CO}_{2}-\mathrm{C}$ loss at the $\mathrm{C}$-rich sites, the application of biochar and $T$. diversifolia did not differ significantly $(P>0.05)$ from each other or from the unamended control (Fig. 1b). Throughout the entire measurement period, the forest floor maintained the lowest $\mathrm{CO}_{2}-\mathrm{C}$ loss in comparison to the $\mathrm{C}$-rich sites. Carbon loss at the $\mathrm{C}$-rich sites was greater than at the $\mathrm{C}$-poor sites regardless of the quality of the applied organic resource. For example, biochar applied to $\mathrm{C}$-rich, less-degraded soil showed $>500 \mathrm{~g} \mathrm{C} / \mathrm{m}^{2}$.year greater losses than on C-poor soil, while C-rich plots to which $T$. diversifolia was applied lost $\sim 100 \mathrm{~g} / \mathrm{m}^{2}$.year more than C-poor, highly degraded plots.

Table 3. Soil carbon changes with organic inputs of differing quality after 2 years of repeated application Maize residue data are adapted from Kimetu et al. (2008) and inserted for comparison. Within columns, values followed by the same letter are not significantly $(P=0.05)$ different from each other. Comparisons are done separately for each period of cultivation and for each column. n.d., No data; n.c., not calculated as isotope difference between soils was insufficient; recovery was calculated using isotopes, and non-recovered $\mathrm{C}$ includes mineralisation as well as physical loss (Nguyen et al. 2008); $n=3$

\begin{tabular}{|c|c|c|c|c|c|}
\hline Treatment & $\begin{array}{c}\text { Crop residues } \\
\text { (t/ha) }\end{array}$ & $\begin{array}{l}\text { Soil carbon } \\
\text { content }(\mathrm{g} / \mathrm{kg})\end{array}$ & $\begin{array}{l}\delta^{13} \mathrm{C} \\
(\% o)\end{array}$ & $\begin{array}{l}\text { Recovery (\% added } \\
\mathrm{C} \text { found in soil) }\end{array}$ & $\begin{array}{c}\mathrm{Net} \mathrm{CO}_{2}-\mathrm{C} \text { loss } \\
\left(\mathrm{mg} / \mathrm{m}^{2} / \text { day }\right)\end{array}$ \\
\hline \multicolumn{6}{|c|}{105 years of continuous cultivation } \\
\hline Biochar & $8.8 \mathrm{~b}$ & $30.5 \mathrm{a}$ & $-20.6 \mathrm{a}$ & $83.8 \mathrm{a}$ & -950 \\
\hline T. diversifolia & $13.8 \mathrm{a}$ & $26.8 b$ & $-20.4 a$ & $23.7 \mathrm{~b}$ & 741 \\
\hline Control & $9.2 \mathrm{~b}$ & $21.1 \mathrm{c}$ & $-18.3 b$ & - & - \\
\hline 1.s.d. $(P=0.05)$ & 2.6 & 1.6 & 1.3 & 21.6 & - \\
\hline \multicolumn{6}{|c|}{35 years of continuous cultivation } \\
\hline Biochar & $6.9 \mathrm{~b}$ & $32.6 \mathrm{a}$ & $-20.0 \mathrm{a}$ & n.c. & n.d. \\
\hline T. diversifolia & $11.8 \mathrm{a}$ & $30.1 \mathrm{a}$ & $-20.3 a$ & n.c. & n.d. \\
\hline Control & $4.9 \mathrm{~b}$ & $24.2 \mathrm{a}$ & $-18.9 \mathrm{~b}$ & & - \\
\hline 1.s.d. $(P=0.05)$ & 3.0 & 9.8 & 0.9 & & - \\
\hline \multicolumn{6}{|c|}{20 years of continuous cultivation } \\
\hline Biochar & $6.6 \mathrm{~b}$ & $36.4 \mathrm{a}$ & $-22.0 \mathrm{a}$ & n.c. & n.d. \\
\hline T. diversifolia & $12.7 \mathrm{a}$ & $32.6 \mathrm{a}$ & $-21.6 b$ & n.c. & n.d. \\
\hline Control & $6.7 \mathrm{~b}$ & $32.6 \mathrm{a}$ & $-21.2 \mathrm{c}$ & & - \\
\hline 1.s.d. $(P=0.05)$ & 2.8 & 5.7 & 0.3 & & - \\
\hline \multicolumn{6}{|c|}{5 years of continuous cultivation } \\
\hline Biochar & $8.2 \mathrm{a}$ & $65.2 \mathrm{a}$ & $-24.6 \mathrm{a}$ & n.c. & 187 \\
\hline T. diversifolia & $10.5 \mathrm{a}$ & $60.2 \mathrm{a}$ & $-24.5 \mathrm{a}$ & n.c. & 658 \\
\hline Control & $10.7 \mathrm{a}$ & $59.9 \mathrm{a}$ & $-24.0 \mathrm{a}$ & & - \\
\hline 1.s.d. $(P=0.05)$ & 2.8 & 6.4 & 1.2 & & - \\
\hline
\end{tabular}




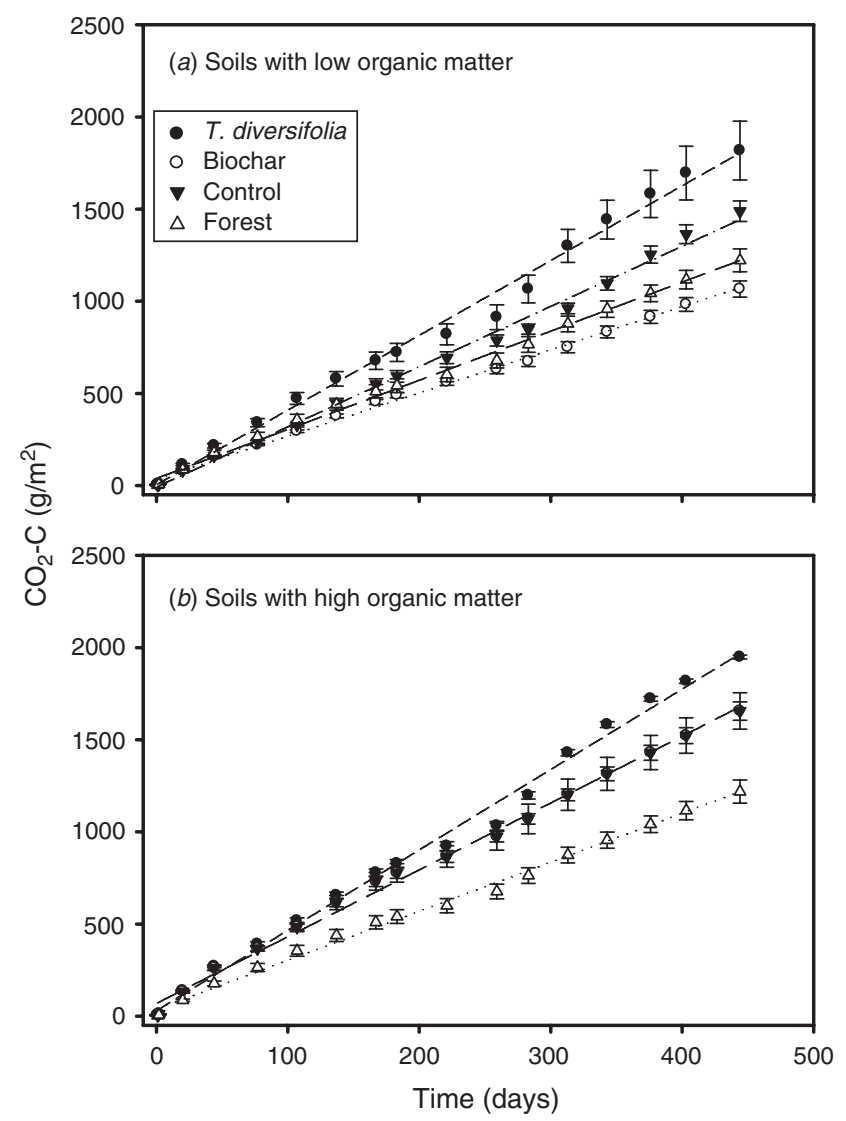

Fig. 1. Cumulative $\mathrm{CO}_{2}$-C loss in (a) C-poor and (b) $\mathrm{C}$-rich Ultisols under different management strategies, 2005-2006. Difference between treatment means was determined by regression analysis $(P=0.0001)$; model: standard linear curve: $y=y_{0}+\mathrm{a}$. Error bars $=$ s.e. $(n=3)$.

\section{Organic carbon in physical fractions}

Effects of added organic matter on $\mathrm{C}$ contents were significant only in the free light and intra-aggregate fractions $(P<0.0001)$, but not in the organo-mineral fraction $(P=0.347)$ (Fig. 2). On average over the entire degradation sequence, significantly $(P=0.042)$ more $\mathrm{C}$ entered free light and intra-aggregate fractions when biochar was applied than after application of T. diversifolia mulch. In both fractions, the difference between biochar and $T$. diversifolia additions significantly $(P<0.1)$ increased from C-rich to C-poor soils (Fig. 2).

\section{FTIR analyses of soils after organic matter additions}

The structural composition of organic $\mathrm{C}$ changed with the application of biochar or $T$. diversifolia (Fig. 3). In C-poor soils, biochar application enriched the proportion of $\mathrm{C}=\mathrm{C}$ of aromatic $\mathrm{C}$ (at $1558-1586 \mathrm{~cm}^{-1}$ ), $\mathrm{C}=\mathrm{O}$ stretching mainly of carboxylic $\mathrm{C}$ and traces of ketones and esters (at 1616.5 and $1697.8 \mathrm{~cm}^{-1}$ ), and $\mathrm{C}-\mathrm{O}$ stretching and $\mathrm{OH}$ deformations of carboxylic $\mathrm{C}$ (at $1385.2 \mathrm{~cm}^{-1}$ ) mainly in the free light and intra-aggregate fractions (Fig. 3). In contrast, application of $T$. diversifolia biomass enriched conjugated carbonyl $\mathrm{C}$ $(\mathrm{C}=\mathrm{O})$ such as ketones and quinones (at $\left.1623.6-1635.9 \mathrm{~cm}^{-1}\right)$ as well as $\mathrm{CH}$ deformations of aliphatic $\mathrm{C}$ (at $1384.5 \mathrm{~cm}^{-1}$ ),

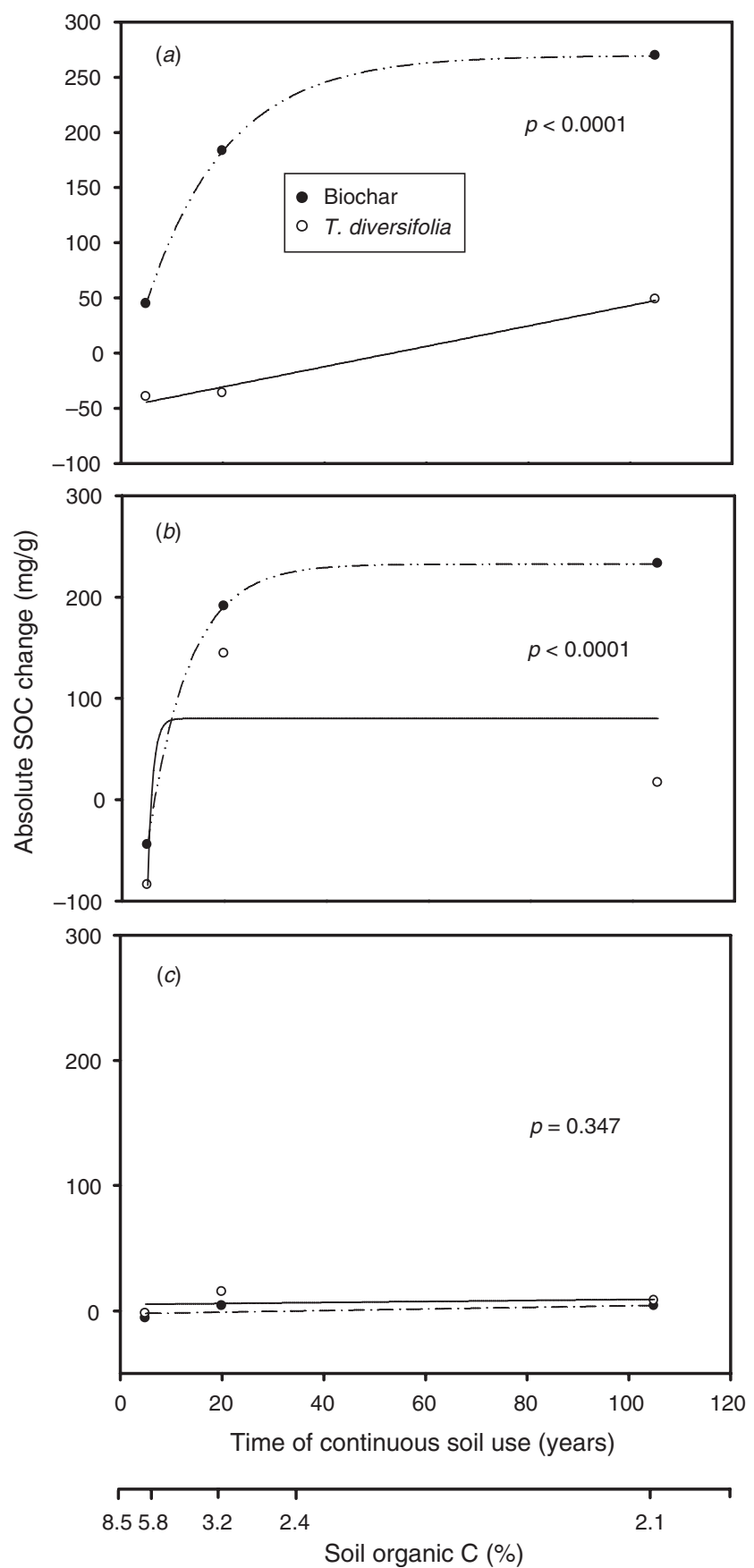

Fig. 2. Influence of organic matter additions on the quantity of SOC in different soil fractions: $(a)$ free light fraction, $(b)$ intra-aggregate fraction, (c) organo-mineral fraction. Measured samples were pooled across 3 replicate farms in each conversion age $(n=1)$. Difference between the slopes was determined at $P=0.05$; models: 3-parameter doubleexponential rise: $y=y_{0}+\mathrm{a}[1-\exp (-\mathrm{b} x)]$ or standard linear curve: $y=y_{0}+\mathrm{a} x$.

mainly in the intra-aggregate fraction. The broad intense bands at $\sim 3443$ and $3421 \mathrm{~cm}^{-1}$ representing $\mathrm{OH}$ stretching vibrations of H-bonded hydroxyl $(\mathrm{O}-\mathrm{H})$ groups of phenol with traces of amine stretches $(\mathrm{N}-\mathrm{H})$ predominated in the free light and intra-aggregate fractions of soils that received either biochar or $T$. diversifolia, while in the control soils this band is 


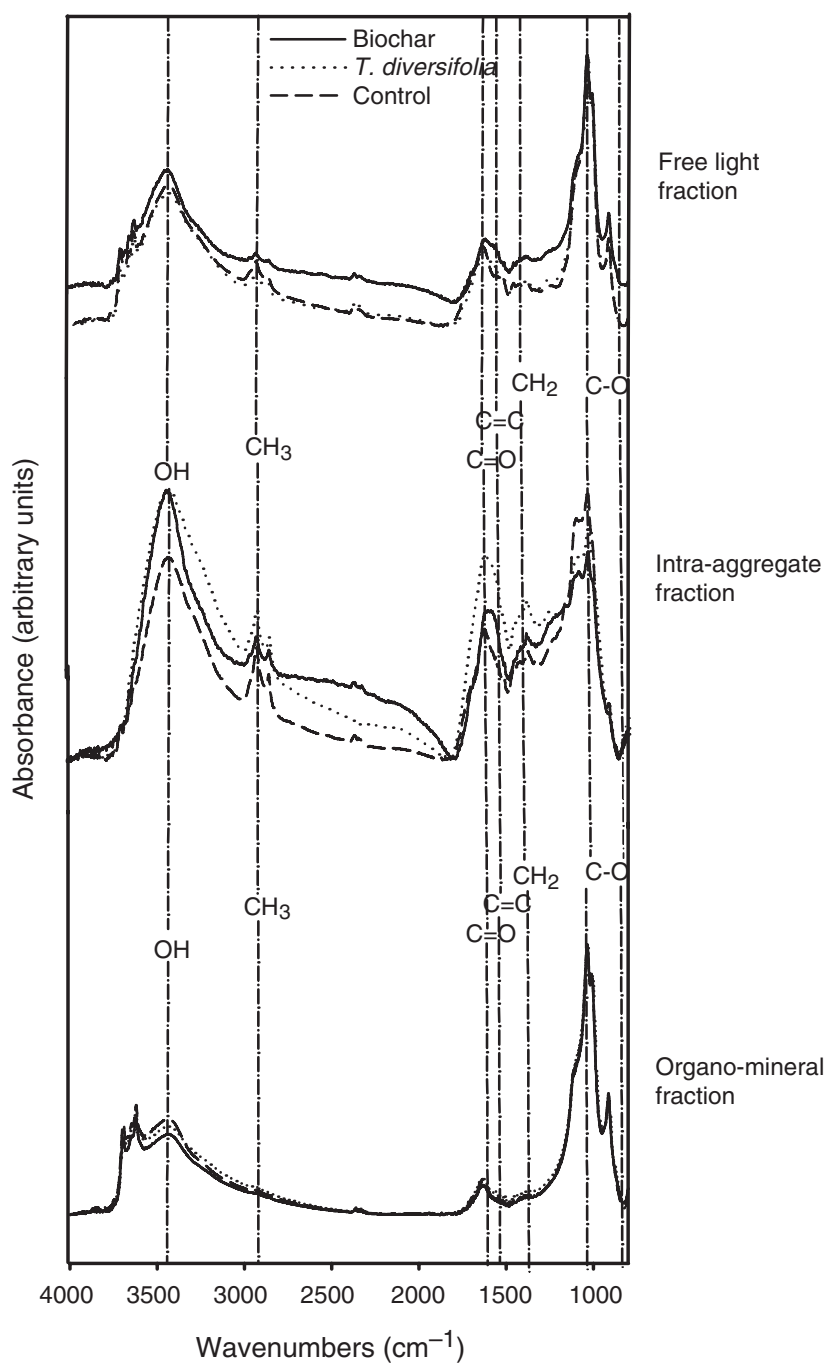

Fig. 3. FTIR analyses of soil fractions from the C-poor soils (105 years of continuous cereal cropping) as a function of the quality of added organic matter.

conspicuously depleted especially in the intra-aggregate fraction (Fig. 3).

\section{Discussion}

\section{Pre-existing SOC and the stabilisation of added} organic carbon

We observed lower absolute increases in $\mathrm{C}$ mineralisation after addition of biochar and T. diversifolia in the C-poor soils, which likely indicates that more $\mathrm{C}$ was stabilised compared with the C-rich soils. This was corroborated by a greater amount of $\mathrm{C}$ accrued in the more stabilised intra-aggregate fraction with decreasing SOC contents. Additionally, even without any OC addition, more $\mathrm{C}$ was lost from the $\mathrm{C}$-rich soil than the $\mathrm{C}$-poor soil at a rate of $0.14 \mathrm{~kg} / \mathrm{m}^{2}$.year, which coincides with a greater microbial biomass (Table 1). Similarly, existing studies in high C-containing soils have shown little or no increase in SOC with increased C inputs (Campbell et al. 1991; Paustian et al. 1997; Solberg et al. 1997; Gulde et al. 2008; Stewart et al. 2008). This supports the saturation concept that soils containing large amounts of $\mathrm{C}$ stabilise less of the $\mathrm{C}$ in added organic matter than soils with low C contents (Hassink 1996; Six et al. 2002; Kimetu et al. 2009). Our observations differ from those made by Knoth (2004), who found that higher C stabilisation could be attained when OC is added to less-degraded soils with greater amounts of SOC. This may be explained by the low levels of aggregation in the coarse-silty mixed mesic Typic Haploxerolls studied by Knoth (2004); whereas, the Kenyan Ultisols studied here are more strongly aggregated. Lehmann et al. (2001) found that for a highly aggregated Xanthic Ferralsol in the central Amazon, the amount of organic $\mathrm{C}$ had no effect on aggregation. Loss of aggregation and therefore reduced capacity to stabilise added organic matter within aggregates may not have played a role at the current study sites.

Effects of added OM quality on the quantity and quality of stabilised $C$

Although the actual rate and degree of OC decomposition is controlled by the decomposer community and environmental conditions, the quality of the decomposing organic resource regulates the potential rate and the resultant end products of the decomposition process (Giller and Cadisch 1997). The quality of added OC may influence not only the amount of undecomposed OC but also the fluxes of decomposing OC between soil fractions. Application of biochar increased total OC contents as well as OC contents in the intra-aggregate fraction to a greater extent than application of $T$. diversifolia with lower OC contents of the soil $(P<0.0001)$. When expressed as the proportion of OC increase per unit $\mathrm{C}$ respired, the proportion of $\mathrm{OC}$ found in the intra-aggregate fractions was 6.8 times greater after adding lowquality biochar than high-quality green manure averaged across the degradation gradient $(P=0.042 ; n=3)$. Thus, we see that the OC remaining in the light fraction after adding biochar will be incorporated into the intra-aggregate and organo-mineral fractions that are typically interpreted as the more stable soil fractions (Six et al. 2002; Zimmermann et al. 2007). Therefore, low-quality biochar not only remained unprocessed but could be stabilised to a greater degree in soil in the long term. These observations agree with the conclusion made by Mapfumo et al. (2007), who indicate that low-quality organic resources increase the size of the free light fraction. This may be explained by a slower processing of added OC by microorganisms as shown by lower $\mathrm{CO}_{2}$ evolution and therefore a greater opportunity for the added $\mathrm{OC}$ to be incorporated into aggregates and for sorption onto minerals. Alternatively, the more rapid $\mathrm{C}$ accrual in more stable SOC fractions may be explained with a more rapid incorporation of applied litter into stable soil fractions in soils that are rich in black C (Liang et al. 2010), which was also indicated by soils amended with biochar (Kuzyakov et al. 2009).

Our findings are, however, contrary to the observations by Wardle et al. (2008), who indicate that biochar can prime humus decomposition. The difference may be explained by the fact that those researchers carried out their work in high C-containing organic horizons, whereas in the present study the positive effect of biochar was clearly observed in the low C-containing mineral soils. Our results corroborate laboratory results by Kuzyakov et al. (2009) and Spokas et al. (2009), who in their incubation 
experiments showed lower, rather than higher, $\mathrm{CO}_{2}$ evolution after biochar addition to soils. Major et al. (2010) found greater emissions from biochar-applied plots that could be explained by greater primary productivity in their study sites. In our experiment, we excluded plant growth from the $\mathrm{CO}_{2}$ chambers and primary productivity would not have been captured. This may explain why, in contrast to Major et al. (2010), we found a net reduction in $\mathrm{CO}_{2}$ emissions.

The greater abundance of aromatic $\mathrm{C}$ in all fractions including the organo-mineral fraction with additions of the stable biochar suggests that the stabilised organic matter bears a chemical signature of the added OM, in this case aromatic $\mathrm{C}$. This greater stabilisation of biochar was more pronounced in the C-poor soils with lower SOC contents. This can be attributed to the lower total amounts of $\mathrm{C}$ mineralised with biochar additions than without, which may indicate that the pre-existing SOC was mineralised to a lesser degree. As demonstrated by Liang et al. (2010) and Neill (2007), microbial populations could be even higher in soils rich in black C. Thus, this decrease in microbial activity is unlikely to be attributed to a decrease in microbial biomass. Therefore, the other possible explanation for this phenomenon could be the reduction in the accessibility of $\mathrm{C}$ by the microbes and enzymes, possibly due to sorption of the labile $\mathrm{C}$ to the added biochar (Pietikäinen et al. 2000; Lehmann et al. 2005). A second explanation could be a possible, more-rapid stabilisation of native SOC (non-biochar $\mathrm{C}$ ) into intra-aggregate and organomineral fractions (Liang et al. 2010).

\section{Conclusions}

In this study we demonstrate that stabilisation of biochar is an important process in soil that influences its residence time, and is therefore dependent on existing soil organic matter. The data in this study indicate that not only the stability but also the stabilisation of biochar exceeds that of a labile organic matter addition such as green manure. Greater increases in total SOC and greater stabilisation of added $\mathrm{C}$ could be attained with biochar due not only to greater amounts of undecomposed OC but to greater incorporation into more stable soil fractions. Biochar resulted in reduced mineralisation losses of existing soil $\mathrm{C}$, which is most likely a result of greater stabilisation of the pre-existing $\mathrm{C}$. The mechanisms remain unclear and require further studies. Particularly, the mechanisms by which soil mineralogy and texture interact with biochar and affect cycling of pre-existing soil $\mathrm{C}$ and microbial communities warrants further research.

\section{Acknowledgments}

This material is based upon work supported by the National Science Foundation (NSF) under grant No. 0215890 and the Rockefeller Foundation under grant No. 2004 FS 104. Any opinions, findings, and conclusions or recommendations expressed in this material are those of the authors and do not necessarily reflect the views of the NSF. We would like to express our appreciation to field and laboratory technicians, Wilson Okila, Joseph Njeri, Wycliffe Kiilu, and Wilson Ngului who were very instrumental in the implementation of this work. We would like to thank Dr David Mbugua for coordinating the work both in the field and in the laboratory and the ICRAF-Kisumu office for logistical support. Many thanks to the Lehmann laboratory group at the Department of Crop and Soil Sciences,
Cornell University, for their encouragement and moral support throughout this study.

\section{References}

Baldock JA, Skjemstad JO (2000) Role of the soil matrix and minerals in protecting natural organic materials against biological attack. Organic Geochemistry 31, 697-710. doi:10.1016/S0146-6380(00)00049-8

Baldock JA, Smernik RJ (2002) Chemical composition and bioavailability of thermally altered Pinus resinosa (Red pine) wood. Organic Geochemistry 33, 1093-1109. doi:10.1016/S0146-6380(02)00062-1

Balesdent J, Mariotti A (1996) Measurement of soil organic matter turnover using ${ }^{13} \mathrm{C}$ natural abundance. In 'Mass spectrometry of soils'. (Eds TW Boutton, S Yamasaki) pp. 83-111. (Marcel Dekker: New York)

Bélanger N, Côté B, Fyles JW, Courchesne F, Hendershot WH (2004) Forest regrowth as the controlling factor of soil nutrient availability 75 years after fire in a deciduous forest of Southern Quebec. Plant and Soil 262, 363-372. doi:10.1023/B:PLSO.0000037054.21561.85

Bernoux M, Cerri CC, Neill C, de Moraes (1998) The use of stable carbon isotopes for estimating soil organic matter turnover rates. Geoderma 82, 43-58. doi:10.1016/S0016-7061(97)00096-7

Brookes PC, Landman A, Pruden G, Jenkinson DS (1985) Chloroform fumigation and the release of soil nitrogen: a rapid direct extraction method to measure microbial biomass nitrogen in soil. Soil Biology \& Biochemistry 17, 837-842. doi:10.1016/0038-0717(85)90144-0

Brown R (2009) Biochar production technology. In 'Biochar for environmental management: science and technology'. (Eds J Lehmann, S Joseph) pp. 127-146. (Earthscan: London)

Campbell CA, Bowren KE, Schnitzer M, Zentner RP, Townley-Smith L (1991) Effect of crop rotations and fertilization on soil biochemical properties in a thick Black Chernozem. Canadian Journal of Soil Science 71, 377-387.

Chun Y, Sheng G, Chiou CT (2004) Evaluation of current techniques for isolation of chars as natural adsorbents. Environmental Science \& Technology 38, 4227-4232. doi:10.1021/es034893h

Edwards NT (1982) The use of soda-lime for measuring respiration rates in terrestrial systems. Pedobiologia 23, 321-330.

FAO-UNESCO (1997) 'Soil map of the world.' Revised Legend. (ISRIC: Wageningen Netherlands)

Gachengo CN, Palm CA, Jama B, Otieno C (1999) Tithonia diversifolia and senna green manures and inorganic fertilizers as phosphorus sources for maize in Western Kenya. Agroforestry Systems 44, 21-36. doi:10.1023/ A:1006123404071

Giller KE, Cadisch G (1997) Driven by nature: a sense of arrival or departure. In 'Driven by nature: Plant litter quality and decomposition'. (Eds G Cadisch, KE Giller) pp. 393-399. (CAB International: Wallingford, UK)

Glaser B, Lehmann J, Zech W (2002) Ameliorating physical and chemical properties of highly weathered soils in the tropics with charcoal - a review. Biology and Fertility of Soils 35, 219-230. doi:10.1007/s00374002-0466-4

Grogan P (1998) $\mathrm{CO}_{2}$ flux measurement using soda lime: Correction for water formed during $\mathrm{CO}_{2}$ adsorption. Ecology 79, 1467-1468. doi:10.1890/0012-9658(1998)079[1467:CFMUSL]2.0.CO;2

Gulde S, Chung H, Amelung W, Chang C, Six J (2008) Soil carbon saturation controls labile and stable carbon pool dynamics. Soil Science Society of America Journal 72, 605-612. doi:10.2136/ sssaj2007.0251

Hassink J (1996) Preservation of plant residues in soils differing in unsaturated protective capacity. Soil Science Society of America Journal 60, 487-491. doi:10.2136/sssaj1996.03615995006000020021x

Huggett RJ (1998) Soil chronosequences, soil development, and soil evolution: a critical review. Catena 32, 155-172. doi:10.1016/S03418162(98)00053-8 
Huggins DR, Allmaras RR, Clapp CE, Lamb JA, Randall GW (2007) Corn-soybean sequence and tillage effects on soil carbon dynamics and storage. Soil Science Society of America Journal 71, 145-154. doi:10.2136/sssaj2005.0231

Huggins DR, Clapp CE, Allmaras RR, Lamb JA, Layese MF (1998) Carbon dynamics in corn-soybean sequences as estimated from natural carbon13 abundance. Soil Science Society of America Journal 62, 195-203. doi:10.2136/sssaj1998.03615995006200010026x

Jama B, Palm CA, Buresh RJ, Niang A, Gachengo C, Nziguheba G, Amadalo B (2000) Tithonia diversifolia as a green manure for soil fertility improvement in western Kenya: a review. Agroforestry Systems 49, 201-221. doi:10.1023/A:1006339025728

Kimetu JM, Lehmann J, Kinyangi JM, Cheng CH, Thies J, Mugendi DN, Pell A (2009) Soil organic C stabilization and thresholds in C saturation. Soil Biology \& Biochemistry 41, 2100-2104. doi:10.1016/j.soilbio. 2009.07.022

Kimetu JM, Lehmann J, Ngoze S, Mugendi DN, Kinyangi JM, Riha S, Verchot L, Recha JW, Pell A (2008) Reversibility of soil productivity decline with organic matter of differing quality along a degradation gradient. Ecosystems 11, 726-739. doi:10.1007/s10021-008-9154-z

Kimetu JM, Mugendi DN, Palm CA, Mutuo PK, Gachengo CN, Bationo A, Nandwa S, Kungu JB (2004) Nitrogen fertilizer equivalencies of organic materials of differing quality and optimum combination with inorganic nitrogen sources in Central Kenya. Nutrient Cycling in Agroecosystems 68, 127-135. doi:10.1023/B:FRES.0000019043.33580.a6

Kinyangi JM (2008) Soil degradation, thresholds and dynamics of long-term cultivation: From landscape biogeochemistry to nanoscale biogeocomplexity. PhD Dissertation, Cornell University, Ithaca, NY, USA.

Knoth K (2004) Fate of organic C and N in long-term agroecosystem experiments using ${ }^{13} \mathrm{C}$ and ${ }^{15} \mathrm{~N}$ labeled plant residues. MS Thesis, University of Berlin, Germany.

Kuzyakov Y, Subbotina I, Chen H, Bogomolova I, Xu X (2009) Black carbon decomposition and incorporation into microbial biomass estimated by ${ }^{14} \mathrm{C}$ labeling. Soil Biology \& Biochemistry 41, 210-219. doi:10.1016/j.soilbio.2008.10.016

Laird D, Brown RC, Amonette JE, Lehmann J (2009) Review of the pyrolysis platform for coproducing bio-oil and biochar. Biofuels, Bioproducts \& Biorefining 3, 547-562. doi:10.1002/bbb.169

Lehmann J (2007) Biochar for mitigating climate change: carbon sequestration in the black. Forum Geoöekologie 18, 15-17.

Lehmann J, Cravo MS, Zech W (2001) Organic matter stabilization in a Xanthic Ferralsol of the central Amazon as affected by single trees: chemical characterization of density, aggregate, and particle size fractions. Geoderma 99, 147-168. doi:10.1016/S0016-7061(00) 00070-7

Lehmann J, Gaunt J, Rondon M (2006) Biol.-char sequestration in terrestrial ecosystems - a review. Mitigation and Adaptation Strategies for Global Change 11, 403-427. doi:10.1007/s11027-005-9006-5

Lehmann J, Liang B, Solomon D, Lerotic M, Luizão F, Kinyangi J, Schäfer T, Wirick S, Jacobsen C (2005) Near-edge X-ray absorption fine structure (NEXAFS) spectroscopy for mapping nano-scale distribution of organic carbon forms in soil: Application to black carbon particles. Global Biogeochemical Cycles 19, GB1013. doi:10.1029/2004GB00 2435

Liang B, Lehmann J, Sohi SP, Thies JE, O’Neill B, Trujillo L, Gaunt J, Solomon D, Grossman J, Neves EG, Luizão FJ (2010) Black carbon affects the cycling of non-black carbon in soil. Organic Geochemistry 41, 206-213. doi:10.1016/j.orggeochem.2009.09.007

Liang B, Lehmann J, Solomon D, Kinyangi J, Grossman J, O’Neill B, Skjemstad JO, Thies J, Luizão FJ, Petersen J, Neves EG (2006) Black carbon increases cation exchange capacity in soils. Soil Science Society of America Journal 70, 1719-1730. doi:10.2136/sssaj2005.0383
Major J, Lehmann J, Rondon M, Goodale C (2010) Fate of soil-applied black carbon: downward migration, leaching and soil respiration. Global Change Biology 16, 1366-1379. doi:10.1111/j.1365-2486.2009. 02044.x

Major J, Steiner C, Downie A, Lehmann J (2009) Biochar effects on nutrient leaching. In 'Biochar for environmental management: science and technology'. (Eds J Lehmann, S Joseph) pp. 271-287. (Earthscan: London)

Mapfumo P, Mtambanengwe F, Vanlauwe B (2007) Organic matter quality and management effects on enrichment of soil organic matter fractions in contrasting soils in Zimbabwe. Plant and Soil 296, 137-150. doi:10.1007/s11104-007-9304-7

Mikan CJ, Abrams MD (1995) Altered forest composition and soil properties of historic charcoal hearths in southeastern Pennsylvania. Canadian Journal of Forest Research 25, 687-696. doi:10.1139/x95-076

Neill BE (2007) Microbial communities in Amazonian dark Earth soils analyzed by culture-based and molecular approaches. MS Thesis, Cornell University, Ithaca, NY, USA.

Ngoze S (2008) Soil nutrient depletion and repletion in a tropical agroecosystem. PhD Dissertation, Cornell University, Ithaca, NY, USA.

Ngoze S, Riha S, Lehmann J, Kinyangi J, Verchot L, Mbugua D, Pell A (2008) Nutrient constraints to tropical agroecosystem productivity in long-term degrading soils. Global Change Biology 14, 2810-2822. doi:10.1111/j.1365-2486.2008.01698.x

Nguyen B, Lehmann J, Kinyangi J, Smernik R, Riha SJ, Engelhard MH (2008) Long-term black carbon dynamics in cultivated soil. Biogeochemistry 89, 295-308. doi:10.1007/s10533-008-9220-9

Novak JM, Busscher WJ, Watts DW, Laird DA, Ahmedna MA, Niandou MAS (2010) Short-term $\mathrm{CO}_{2}$ mineralization after additions of biochar and switchgrass to a Typic Kandiudult. Geoderma 154, 281-288. doi:10.1016/j.geoderma.2009.10.014

Palm CA, Gachengo CN, Delve RJ, Cadisch G, Giller KE (2001) Organic inputs for soil fertility management in tropical agroecosystems: application of an organic resource database. Agriculture, Ecosystems \& Environment 83, 27-42. doi:10.1016/S0167-8809(00)00267-X

Paustian K, Collins HP, Paul EA (1997) Management controls on soil carbon. In 'Soil organic matter in temperate agroecosystems'. (Eds EA Paul, K Paustian, ET Elliott, CV Cole) pp. 15-49. (CRC Press: Boca Raton, FL)

Pietikäinen J, Kiikkilä O, Fritze H (2000) Charcoal as a habitat for microbes and its effects on the microbial community of the underlying humus. Oikos 89, 231-242. doi:10.1034/j.1600-0706.2000.890203.x

Puget P, Drinkwater LE (2001) Short-term dynamics of root- and shoot-derived carbon from a leguminous green manure. Soil Science Society of America Journal 65, 771-779. doi:10.2136/sssaj2001. 653771x

Rothamsted Experimental Station (2005) 'GenSTAT version 8.2.' (VSN International: Harpenden, Hertfordshire, UK)

Schmidt MWI, Noack AG (2000) Black carbon in soils and sediments: Analysis, distribution, implications, and current challenges. Global Biogeochemical Cycles 14, 777-794. doi:10.1029/1999GB001208

Six J, Conant RT, Paul EA, Paustian K (2002) Stabilization mechanisms of soil organic matter: implications for C-saturation of soils. Plant and Soil 241, 155-176. doi:10.1023/A:1016125726789

Sohi SP, Mahieu N, Arah JRM, Powlson DS, Madari B, Gaunt JL (2001) A procedure for isolating soil organic matter fractions suitable for modeling. Soil Science Society of America Journal 65, 1121-1128. doi:10.2136/sssaj2001.6541121x

Solberg ED, Nyborg M, Izaurralde RC, Malhi SS, Janzen HH, Molina-Ayala M (1997) Carbon storage in soils under continuous cereal grain cropping: $\mathrm{N}$ fertilizer and straw. In 'Management of carbon sequestration in soil'. (Eds R Lal, JM Kimble, RF Follett, BA Stewart) pp. 235-254. (CRC Press: Boca Raton, FL) 
Solomon D, Fritzsche F, Lehmann J, Tekalign M, Zech W (2002) Soil organic matter dynamics in the subhumid agroecosystems of the Ethiopian Highlands: Evidence from natural ${ }^{13} \mathrm{C}$ abundance and particle-size fractionation. Soil Science Society of America Journal 66, 969-978. doi:10.2136/sssaj2002.0969

Spaccini R, Mbagwu JSC, Zena Teshale A, Igwe CA, Piccolo A (2002) Influence of the addition of organic residues on carbohydrate content and structural stability of some highland soils in Ethiopia. Soil Use and Management 18, 404-411. doi:10.1079/SUM2002152

Spokas KA, Koskinen WC, Baker JM, Reicosky DC (2009) Impacts of woodchip biochar additions on greenhouse gas production and sorption/ degradation of two herbicides in a Minnesota soil. Chemosphere 77, 574-581. doi:10.1016/j.chemosphere.2009.06.053

Stewart CE, Paustian K, Conant RT, Plante AF, Six J (2007) Soil carbon saturation: concept, evidence and evaluation. Biogeochemistry 86, 19-31. doi:10.1007/s10533-007-9140-0

Stewart CE, Plante AF, Paustian K, Conant RT, Six J (2008) Soil carbon saturation: Linking concept and measurable carbon pools. Soil Science Society of America Journal 72, 379-392. doi:10.2136/sssaj2007.0104
Thies JE, Rillig MC (2009) Characteristics of biochar: Biological properties. In 'Biochar for environmental management: science and technology'. (Eds J Lehmann, S Joseph) pp. 85-105. (Earthscan: London)

Topoliantz S, Ponge JF, Arrouays D, Ballof S, Lavelle P (2002) Effect of organic manure and endogeic earthworm Pontoscolex corethrurus (Oligochaeta: Glossoscolecidae) on soil fertility and bean production. Biology and Fertility of Soils 36, 313-319. doi:10.1007/s00374-0020535-8

Tryon EH (1948) Effect of charcoal on certain physical, chemical, and biological properties of forest soils. Ecological Monographs 18, 81-115. doi:10.2307/1948629

Wardle DA, Nilsson M, Zackrisson O (2008) Fire-derived charcoal causes loss of forest humus. Science 320, 629. doi:10.1126/science.1154960

Zimmermann M, Leifeld J, Fuhrer J (2007) Quantifying soil organic carbon fractions by infrared-spectroscopy. Soil Biology \& Biochemistry 39, 224-231. doi:10.1016/j.soilbio.2006.07.010

Manuscript received 2 February 2010, accepted 9 July 2010 